\title{
Introduction to the Special Issue
}

\section{History of Education, International Relations and Transnational Perspectives: State of the Art ${ }^{1}$}

\author{
Óscar J. Martín García \\ Universidad Complutense de Madrid \\ Mariano González-Delgado \\ Universidad de La Laguna
}

\section{International Influences as an Object of Study in History of Education}

In recent years there has been a considerable increase in research within the field of the History of Education that focuses on factors, actors and mechanisms that go beyond the state framework (Mangan, 1993; Fuchs, 2007; McCulloch, 2009; Popkewitz, 2009; Bruno-Jofré \& Schriewer, 2012; Droux \& Hofstetter, 2014). Paradoxically, this type of research arose from interest in the educational policies adopted by nation states. Although focused on the study of educational programs at the domestic level, the researchers attracted by this issue agreed on the need to use new theoretical frameworks and analytical perspectives that took into account international processes such as the importation of pedagogical models and the transfer of methodological schemes. (Ramirez \& Boli, 1987; Jones \& Coleman, 2005; Ochs \& Phillips, 2004). In recent years, this approach has been used by various studies. These have pointed out the impacts that connections between individuals or pedagogical ideas from different geographical areas have had on the educational systems of

ISSN 2560-8371

DOI: 10.24908/encounters.v21i0.14310 (C) Encounters in Theory and History of Education | 1 
different countries. The reception of escolanivistas proposals in the Spain in the first half of the 20th century or in other countries at the international level are a good example of this (Del Pozo Andrés \& Braster, 2006; Igelmo-Zildívar, 2012; Otero Urtaza, 2013; Raftery, 2015; Ferraz Lorenzo, 2016; Canales, 2019).

In this sense, the phenomenon of international connections and interactions has also encompassed various educational spheres and processes. For example, within the History of Education, one line of research on the international and transnational dimensions of educational transfer has been that of studies on educational colonialism. Several works, developed mainly from the Anglo-Saxon sphere, have emphasized the influence of metropolises on the construction of national education systems in the colonies (Goodman, McCulloch \& Richardson, 2009; Ossenbach \& Del Pozo Andrés, 2011, Rogers, 2013; Negrín Fajardo, 2013). On the other hand, in recent years, it has become clear how the phenomena of educational internationalization have fostered the creation of multiple personal and institutional connections that have helped shape Education Sciences as a disciplinary and professional field (Jover \& Thoilliez, 2011; McCulloch \& Cowan, 2018). Likewise, today it is known how international conferences, scientific journals and academic networks have shaped this area of educational research from different countries (Charle, Schriewen \& Wagner, 2004).

However, within this new line of research, it should be noted that the processes of educational change do not only involve the exchange of ideas of a pedagogical nature. For example, the transmission of various school models has been a matter widely studied by specialists in the discipline. It is interesting here to point out these works have analyzed how the exchange processes generated attempt to emulate and import school institutions from different countries (Viñao, 1990; Caruso \& Roldán Vera, 2005; Del Pozo Andrés \& Braster, 2017). In the History of Education, the circulation of educational ideas and the implementation of different curricular policies in vocational training and in university institutions have also been investigated, including transformations in non-formal education (Allender, 2016; Igelmo-Zaldívar \& Jover, 2019; Igelmo-Zaldívar, Jover \& Quiroga-Uceda, 2020).

The adoption of this type of perspective has been increasing in recent decades, opening new and stimulating lines of research into educational institutions. Some studies have highlighted the relevance of personnel exchange programs in producing processes of educational change and modernization in recipient countries. In this regard, studies on training programs abroad can be reviewed. These programs have contributed to promoting educational transfers and reforms from below (Phillip \& Ochs, 2004; Groves, 2015; Sivesind \& Wahlström, 2016). Such programs included scholarships and training activities for educational elites, as well as trips and training periods abroad for secondary and university teachers (Delgado Gómez-Escalonilla, 2009; Åkerlund, 2014).

Broadly speaking, these exchange activities can be framed as part of public and private efforts to organize, structure, and institutionalize the transnational movement of 
people and ideas for mainly educational purposes. Scholarship and exchange programs grew remarkably in the last century, involving a vast movement of people and knowledge that have affected cultural and educational transfers internationally. These exchanges have contributed to the creation of transnational networks of educational experts, to the institutionalization of academic disciplines and the adoption of national educational policies. However, these programs have not been explored in the necessary depth by researchers of the History of Education or International Relations. Even though the latter has produced an extensive bibliography on cultural diplomacy and international education during the Cold War, its approach to educational exchanges has suffered from a somewhat superficial, institutional, and hagiographic tone. Therefore, new studies are needed to delve into a transnational and micro-historical perspective, which unravels the networks, itineraries and personal experiences forged in the heat of scholarship and exchange programs. The objective is, therefore, to know in more detail, using a bottom-up approach, how these programs shaped professional careers, formed educational networks and communities, as well as influenced institutions and policies in this field. In this way, it will be possible to shed new light on the role of scholarship and exchange programs in the construction and circulation of knowledge, ideas and practices in the educational field (Tournès \& ScottSmith, 2017).

Although not part of the exchange programs, another issue that has become relevant is that related to the study of the reception of technicians from foreign institutions with the purpose of transferring methodological tools to improve teaching and learning (Ossenbach \& Groves, 2013; González-Delgado \& Groves, 2016; Mahamud Ángulo \& Milito Barone, 2020).

All this research has taken a fundamental first step in understanding the importance of international connections in shaping and molding national education systems. In other words, in the last decades, a series of works have appeared that highlight the difficulty of explaining the development of certain educational policies in different countries through an exclusively national approach (Fuchs, 2014). This does not mean that the concept of the nation-state lacks any explanatory capacity for the analysis of contemporary educational policies. In this regard, some authors have indicated the need to understand the direction of certain policies through the action and mediation exerted by local actors in their implementation (Westberg, 2019; Prytz \& Ringarp, 2020; Goodson \& Mikser, 2020). However, all of them recognize the importance of the phenomena of globalization (and the consequent internationalization) in the redefinition of national narratives about the orientation of educational systems. (Westberg, Boser \& Brühwiler, 2019; Westberg, 2020). 


\section{A New Approach to the History of Education: The Transnational Turn and Studies on the Impact of International Organizations}

Despite the importance of this new international perspective, some researchers have highlighted the need to go further. Studies addressing the international dimension have shown the important role played by external influences in shaping the educational policies of nation-states. These works have also shown the relevance of certain individual connections with educational institutions in other countries. All this has meant important advances in the History of Education. However, it is necessary to study the educational relationships and phenomena that go beyond the national framework from a broader and more complex approach. In short, it is a matter of adopting a transnational historiographic approach, which takes new analytical approaches to the phenomena of globalization and its impact on educational systems (Christensen \& Ydesen, 2015).

To this day, transnational history has produced a rich bibliography on the processes of circulation, interaction and exchange that shape global knowledge and educational practices. A good number of these works make it clear that, although the transnational perspective was originally identified with the movement of goods and money, there is also a focus on people, on the social spaces in which they are related, on the networks that they build and in the ideas that they exchange (Clavin, 2005, p. 422; Goedde, 2017). From a similar perspective, other authors such as Snyder (2003, pp. 100-102) consider that transnationalism does not represent so much a new historiographical field as a methodology that allows studying new actors and their interactions.

This type of approach has fostered a thematic and theoretical shift in the field of diplomatic history and international relations, with a clear impact on education studies. As a result, the number of historians who advocate overcoming the traditional vision of the State as the sole and main actor in the international sphere has increased significantly. These authors include various non-government agents in their research on cultural and educational foreign relations (Laville \& Wilford, 2006; Tyrrell, 2007; Gienow-Hecht \& Donfried, 2010; Weisbrode, 2013). They have also paid attention to the role of "informal" or "citizen diplomats" who complement, or even bypass, the state's efforts in the field of cultural foreign policy (Scott-Smith, 2014). All these contributions have made studies on cultural diplomacy a part of a "well-established yet expanding list of objects of transnational history" (Struck, Ferris \& Revel, 2011, p. 574).

On a different note, one of the issues that have most concerned education historians in recent decades has been the processes of educational convergence that occurred globally after World War II. What factors explain that countries with different political systems, different cultural traditions and even antagonistic educational structures evolved during the second half of the 20th century towards the same idea or concept of education? Far from understanding such processes through local 
dynamics, research has concentrated on the transnational aspects of them. In other words, the History of Education has become increasingly interested in the educational concept that international organizations, diplomatic connections or other exchange phenomena helped to build during the second half of the 20th century. It has also endeavored to understand how this vision of education managed to break the limits to its circulation and transnationalization that purely local actors would have meant. The works of John Meyer, Francisco Ramirez, Richard Rubinson and John Boli on the rise and universalization of educational systems worldwide were a first step in this direction (Meyer, Ramirez, Rubinson \& Boli, 1977). These authors pointed out the importance of "globalization" as a political phenomenon in understanding why different countries underwent similar processes in the expansion and change of their educational structures.

From here, other authors followed similar lines of work. Phillip W. Jones, for example, inquired into the influence that international organizations such as the United Nations Educational, Scientific and Cultural Organization (UNESCO), the Organization for Economic Cooperation and Development (OECD), the World Bank (WB) or the Food and Agriculture Organization (FAO), among others, had on the creation, development and stabilization of certain educational policies (Jones, 1999; Jones \& Coleman, 2005; Ydesen, 2019). These organizations - together with other government agencies, multilateral institutions and non-governmental actors - constituted what the same author has called the "global architecture of education," referring to a complex institutional network in charge of producing, transmitting and financing different policies and educational ideas that influenced the construction of national educational systems (Jones, 2006, p. 48).

One of the main actors within that community of international actors was UNESCO. It played a role of great importance in the processes of educational transfer during the second half of the 20th century. In recent years, numerous studies have appeared on the work of this organization in different countries. This research has analyzed UNESCO's activities in the field of educational modernization, as well as the debates raised within it about Modernization Theory (Graham, 2006; Dorn \& Ghoodse, 2012). There are also studies that explore the influence of UNESCO on the construction and expansion of educational systems in African and Asian countries (Mikobi Dikay, 2016). Other aspects equally addressed include the modernization of school textbooks in connection with international understanding (Nygren, 2011; Kulnazarova \& Ydesen, 2017; González-Delgado, 2018) and the importance of transmitting and configuring certain ideas about building citizenship models in textbooks (González-Delgado, Ferraz-Lorenzo \& Machado-Trujillo, 2019).

In addition, other dimensions of UNESCO's educational policies have been investigated, such as the use of technology in education (Hallström, Hultén \& Lövheim, 2014; González-Delgado, 2020; González-Delgado \& Groves, 2017 and 2020; Alves \& Guimarães Lima, 2018), health education (Terrón, Comelles \& Perdiguero-Gil, 2017), 
environmental education (Ferraz-Lorenzo, 2020, Dorn, 2020), the circulation of books, films and teaching materials (Druik, 2006; Giton, 2016 ) and educational policies related to ideas on Educational Planning and UNESCO's association with other international organizations such as the OECD or the WB (Ossenbach \& Martínez Boom, 2011; Delgado Gómez-Escalonilla, 2015; Mariuzzo, 2016; Corrales-Morales, 2020; GonzálezDelgado \& Groves, 2020).

Since the beginning of this century, various investigations on the importance of globalization processes in the formulation of educational policies at the national level have been undertaken in the field of the History of Education. Authors such as Gary McCulloch and Roy Lowe (2003), Karen Mundy (2006), Thomas Popkewitz and Fazal Rizvi (2009), Catherine Burke, Peter Cunningham and lan Grovenor (2010), Eckhardt Fuchs (2012) or Eugenia Roldán Vera (2013) have made significant contributions to the concept of the transnational turn and its use in the History of Education. Their works address the study of educational systems beyond their specific national spaces. In this way, they highlight the need to analyze the educational policies of the second half of the 20th century considering the mediation work carried out by international institutions.

As Paul Duedahl (2016) has pointed out, emphasizing this perspective allows us to understand some of the most outstanding educational changes produced in the current educational environment. This has been the main contribution of interesting works that, under the orbit of this theoretical approach, as well as expanding the territorial space under analysis. For example, some research in this direction explores the construction of citizenship models through educational policies of an international nature fostered by the expansion of educational systems after World War II (Trölher, Popkewitz \& Labaree, 2011). Such works try to understand how the flow and circulation of ideas configured a certain vision about notions such as freedom, individuality, progress, rationalism and, therefore, citizenship itself worldwide (Trölher, 2013). To a certain extent, this line of research collects theoretical perspectives on the world system (Wallestein, 1974) and tries to apply them to the field of education.

The possibility of proposing new objects of study within the framework of this new approach does not end with the construction of citizenship models. Some authors have pointed out the need to unravel in a more detailed and specific way the real impact and ways in which these educational transfer processes were established (Duedahl, 2016). In recent years, some studies have appeared that indicate the importance of the Cold War in modifying curricular policies at the international level. For example, John L. Rudolph has studied how science curricula and teaching processes were altered in the United States as a result of the impact of the Soviet launch of Sputnik. This historical event produced a deep debate in various educational settings within the United States. In the heat of this discussion, a multitude of modifications arose in science teaching, as well as in the development of new educational policies in the US (Rudolph, 2002). However, such changes not only 
affected the science curriculum. The Cold War had an important impact on the lifestyles and values of American society, promoting the implementation of new knowledge about social studies in the country's schools (Evans, 2011) and in the schools of some of its allies in this bipolar conflict (Isozaki, 2016; Christophe, Gautschi \& Thorp, 2019).

As various studies have highlighted, education acquired an important international dimension in the Cold War. In this period, it went from being a mainly domestic issue to becoming an international issue (Lindo-Fuentes \& Ching, 2012; Snider, 2013; Martín García \& Delgado, 2020). In the context of the 1950s and 1960s, education became a component of North-South relations and East-West competition. Such a rise in the international relevance of education was closely connected with two phenomena. On the one hand, from the 1950s, factors such as (1) decolonization, (2) global social change, and (3) the emergence of an incipient society of mass consumption and new urban middle classes caused an explosion in educational demand in the Third World. The increase in educational aspirations of developing societies drove a significant expansion of their educational systems, which in turn led to an unprecedented crisis in them (Arnove 1980; Meyer, Ramirez, Rubinson \& Boli, 1977; Coombs, 1968). A true reflection of this crisis was the appearance during the 1960s of student protests and disorders in a good number of countries in Asia, Africa, Latin America and Southern Europe (Christiansen \& Scarlett, 2013; Martín-García, 2019).

On the other hand, between the 1950s and 1970s, there was strong competition between the Cold War blocks to promote, regulate and guide the economic and social development of the backward nations. Within international history, a vibrant field of study is tasked with examining such competition for control of the Third World. According to these works, in the middle decades of the 20th century, the southern hemisphere became the main battleground between two modernization models that aspired to transform the global periphery into its image and likeness. From this perspective, East-West rivalry is seen as an ideological struggle between two antagonistic concepts of global social change and the definition of modernity. On the one hand, the archetype of Soviet development was inspired by class struggle and Marxist utopia. On the other, the main instrument used by the United States in this contest to win the hearts and minds of traditional societies was its Modernization Theory (Westad, 2000, 2003; Latham, 2010; McMahon, 2013).

This theory emerged as part of the American response to the intellectual and political challenge compounded by decolonization, global social change, and the spread of communism in the Third World. First and foremost, it was a social scientific paradigm aimed at analyzing and understanding the impetuous and profound transformations brought about by the fall of the European empires. Second, from an ideological artifact aimed at guiding and channeling such changes in a direction favorable to American interests in the Cold War. As such a device of political control, Modernization Theory not only had a scientific-analytical function, but also a normative 
one. It prescribed how traditional societies should move toward modernization at the apex of which was the United States.

While the Soviets extolled the virtues of state planning, the development ideal prescribed by American modernizers presented technology, science, expert knowledge, productivity, and efficient and rational planning as antidotes to the communist revolution. Inspired by the ideas of the Chicago School of Human Capital Theory, this vision of modernization also considered that education played a fundamental role in promoting national development. Economists linked to this school such as Theodore Schultz, W. Arthur Lewis, Frederick H. Harbison and Gary Becker, among others - defended that education represented a valuable productive investment, essential to train the qualified workforce that development required. These social scientists saw education as a central element in promoting economic and social progress. They also conceived it as a useful tool for disseminating in backward societies the modern values, attitudes, and methods that were required to drive development and prevent the spread of revolutionary ideas (Schultz, 1968; Dorn \& Ghodsee, 2012, pp. 383- 385; Jones \& Coleman, 2005, p. 3). Ultimately, according to the proponents of Modernization and Human Capital theories, education provided the training and mindset necessary to move the lever of development in an orderly, stable direction, favorable to the strategic priorities of the West in the Cold War.

Influenced by these ideas, American experts and diplomats pointed to education systems as one of the main obstacles to the progress of backward nations. These nations had outdated systems, the structural deficiencies of which hindered development, perpetuated traditional mentalities, nurtured student disaffection, and made these societies more vulnerable to communism. To avoid such threats, the US government tried to stimulate educational reform in countries on the global periphery. The purpose of the American superpower was to modernize the flawed educational architecture of these countries, put education at the service of development, and neutralize student discontent. To achieve this goal, US diplomacy deployed, in addition to financial aid programs and technical and educational assistance, numerous public diplomacy activities. These were aimed at connecting and familiarizing the educational elites of the Third World with the concepts, methods, and achievements of the educational system in the United States.

However, in relation to public diplomacy and educational modernization programs, it should be noted that the United States was not the only active Western power in this field. During the Cold War, British, French and West Germans, among others, also launched cultural and information initiatives that aimed to influence educational policies in other countries, including those behind the Iron Curtain. For example, Andreas Åkerlund (2015) has studied the role of the Swedish Institute in the processes of educational transfer in Eastern Europe from the late 1940s. Likewise, it is pertinent to highlight that the educational transfers transmitted through public diplomacy did not always follow a one-way direction, often producing mutual influences, reciprocal ties 
and processes of educational entanglement (Sobe, 2013). A phenomenon that is not exclusive to this period and that already has antecedents that have been explored by works such as those of Mari Hiraoka (2020) and Linda Chisholm (2020).

A considerable number of studies into public diplomacy in the Cold War have emerged in recent years. These contributions have contributed to expanding and diversifying the field. However, it continues to be dominated by investigations into the American case (Osgood \& Etheridge, 2010: 6). Broadly speaking, studies focused on the Cold War period understand public diplomacy as the set of activities deployed by governments, private entities and civil society groups in the fields of education, communication and culture aimed at establishing a direct and fluid dialogue with foreign audiences in order to (1) disseminate among them information about the values, culture and institutions of a particular country or organization, and (2) attract and persuade such audiences in order to shape their views on diverse domestic and international issues and, Ultimately, those of their governments (Gilboa, 2008).

As N. Snow (2009) observes, this approach to public diplomacy is linked to power, particularly to soft power. This concept was coined by J. Nye in the early 1990s. Since then it has achieved great popularity, becoming a subject of debate between scholars, practitioners, policymakers and media analysts. J. Nye $(1990,2004,2008)$ defines soft power as the ability to shape the preferences of others by attraction rather than coercion. According to this author, soft power is the capacity of attraction that a specific international actor exerts without needing to use military force or economic sanctions. While this power resides in an actor's resources in terms of its culture, values, institutions and policies, the concept of public diplomacy refers to the tools (international broadcasting, printed media and libraries, cultural presentations, educational exchanges) used to mobilize such resources to radiate international ideological influence.

Although both concepts have faced criticism during the past few years, the notions of public diplomacy and soft power have helped to deepen the study of the cultural dimensions of the American-Soviet rivalry. Work from this perspective has highlighted that in the Cold War 'cultural life and cultural institutions moved from the sidelines to the center of the political confrontation' (Gienow-Hecht, 2010, p. 401). As D. Caute (2005, p. 3) points out, the bipolar competition in areas such as cinema, music, literature, theatre and television represents a 'unique historical phenomenon', in which virtually every aspect of cultural life took on a political meaning and, therefore, could potentially be used as a tool to engage public opinion abroad. Education was also a contested sphere in this cultural Cold War for persuading foreign audiences of the superiority of the respective political, economic and social systems. However, this is a field that is still little explored by the History of Education. A weakness that, in order to be corrected, will require a greater dialogue with the cultural history of international relations. 
In short, this transnational turn in the History of Education seems to continue to produce a considerable number of works on the importance that the flow and exchange networks of ideas have played in understanding the construction of national education systems since their very creation (Bachi, Fuchs \& Rousmariene, 2014; Duedhal, 2016; Fuchs \& Roldan Vera, 2019; Martín García \& Delgado GómezEscalonilla, 2020; McCulloch, Goodson \& González-Delgado, 2020). The importance exerted by the Cold War, Modernization Theory, international organizations or diplomatic connections are central elements from which to understand why countries with such diverse political processes developed similar educational and curricular projects in different historical periods. To some extent, this framework also allows us to understand the conceptual logic on which these educational systems operated and to understand how and why certain educational policies have been produced since the Second World War.

\section{Conclusions}

One of the lines of investigation in the field of History of Education in the last decades has been to analyze the processes of pedagogical importation and exchange between different educational models in different historical epochs. This aspect produced significant efforts to understand the impact that certain escolanovistas models had among countries, especially in the western sphere. In such studies, we can find the origin of these investigations that emphasized the importance international connections can have in understanding some of the most notable educational changes within contemporary educational systems.

However, these lines of research did not close with these first analyses. Some researchers within the field of the History of Education observed the importance of expanding this type of perspective. International influences went beyond institutional aspects. After World War II, educational systems seemed to develop similar educational policies despite presenting different political systems or diverse cultural traditions. With this, the need to expand the theoretical frameworks from which to approach this field of study was observed. This aspect involved the introduction of what has become known as transnational history. For the first time, education historians pointed out the importance that new personal and institutional networks that went beyond the spaces of nation-states had in the configuration of the educational systems of the second half of the 20th century.

From here, a significant number of works emerged that pointed to the central role that organizations such as the UNESCO or the OECD had in shaping educational models in different countries. In addition, other research also addressed the impact that the context of the Cold War or Modernization Theory had on the educational field during this period. Despite all the research carried out in recent years, some 
investigators have suggested the need to keep probing deeper into the impact of this phenomenon. In fact, such research would involve further investigation into the phenomena that the aforesaid context has generated. We refer to new strategies of Public Diplomacy and connections or links between institutions, cultural spaces and people generated in the international space and that have had notable impacts on the configuration of educational systems after World War II.

This special issue tries to delve into these areas of study. We intend to advance in our knowledge of the importance that the Cold War, the phenomena of public diplomacy, the impact of international organizations and Modernization Theory had on the configuration of national education systems during the second half of the 20th century. All this will allow us to better understand what the global governance devices of school systems have been in recent decades and to comprehend in detail the reasons for educational policy trends today.

After World War II educational systems worldwide underwent a remarkable transformation. A new global architecture was produced in all areas of education. This expansion not only increased the universalization of educational systems. With it, modifications also arose in educational policy, curriculum, teacher training or teaching methods. It is even worth noting the transformation that the field of educational research also experienced. All of them grew under the protection of new networks or new devices that were promoted by international organizations such as UNESCO, the OECD, the WB or the WHO. However, other multilateral cooperation organizations created by different national states also helped to create this global network in education: The Ford Foundation or USAID are good example of this.

In recent years, the History of Education has concentrated an important part of its efforts in investigating such internationalization phenomena and how they have affected the development of national education systems. This fact has meant that within the historical-educational field new perspectives of analysis called transnational turn have been generated. This special issue aims to deepen this perspective. It tries to advance, reflect and debate about the importance that transnational processes have had in the configuration of different educational spaces. In addition, it is also intended to observe the extent to which local actors helped shape these transformations and the convergence and relationships they established with transnational institutions.

As the reader has been able to verify, the first article of this special issue has tried to delimit the scope of the transnational turn within the field of the History of Education. Not only have the main research carried out on the reception, exchange and transfer of educational ideas been presented. The article also intends to point out to readers the importance of the development of transnational research to better understand the 
development of educational systems after the Second World War. In this sense, this work indicates the mediation and influence that international organizations such as the OECD, UNESCO or the WB have had. They have functioned as educational actors that have mediated the process of construction of educational policy, the curriculum, teacher training or textbooks. In addition, the importance of the Cold War contexts and the Modernization Theory have also been seen in this process. All of this has led to the advancement of research to try to better understand how the devices of global governance in education have developed. We trust that this work will serve to place the reader in the academic debate that is taking place within the field of the history of education and will be a stimulus to join it.

The second of the articles in this special issue focuses on one of the main educational actors that gave rise to the current educational concept. Rita Hofstetter and Bernard Schneuwly have made an important study of the origin and development of the International Bureau of Education (IBE). One of the leading educational institutions that helped shape and develop the field of educational sciences internationally. In addition, the article advances to the merger of the same with UNESCO and how both institutions walked together in the realization of new forms of educational internationalism.

The third article addresses another of the great spaces that fostered educational transfer processes during the second half of the 1970s. The work of Professor Letterio Todaro, addresses the development of the discipline of Comparative Education in Italy. This research allows us to understand not only its development and stabilization in the Mediterranean country. The very contemporary origin of Comparative Education in Italy speaks to us of the importance that international organizations had in it. On the other hand, the work also highlights the process of disenchantment that occurred around it. The reader must bear in mind that Comparative Education functioned as a scientific entity that was supposed to be able to develop better and broader changes and modernization of educational systems. The article, therefore, also advances in the different criticisms that were developed towards the aforementioned discipline in Italy in the seventies.

The fourth article is situated in a more general space of great interest, for several reasons. The work presented by the CSIC researcher Lorenzo Delgado GómezEscalonilla focuses on analyzing the impact that international organizations had on the process of the educational path during the Franco dictatorship. On the one hand, the article tries to reflect the specific weight that UNESCO, the OECD or the WB played in producing educational modernization processes in the Spain of the dictatorship. On the other hand, an interesting idea is pointed out that should also be put on the table. The Spanish example is an interesting case study to understand the origin of global governance in education. It must be borne in mind that, in various cases, the Iberian country functioned as a pilot geographic space for the implementation of educational 
policies that international organizations considered adequate to achieve the economic development objectives proposed by them.

The fifth article, written by Professor Joaquim Pintassilgo, is located in the Portuguese space and also within the dictatorship. It aims to investigate how alternative pedagogies were introduced in a Portugal dominated by an authoritarian government. The author begins by analyzing the reception of such alternative educational and new school perspectives in the 1950s. The work progresses to the decade of the seventies of the twentieth century. It points out to us not only the importance of a group of progressive teachers in a country corseted in a dictatorial space. Also, it indicates to us the importance that the international connections of these teachers had in producing an educational transfer process. Finally, the reader will be able to observe the importance of the debate posed by Professor Pintassilgo, insofar as he speaks of the fragile lines that sometimes have the relationships between "traditional and innovative" in the pedagogical field.

The sixth article returns to focus on the Spanish context. But this time, a very specific case is analyzed and of great interest from the point of view of transnational history: The Labor Universities. This work, written by the researchers María Dolores Molina Poveda and Carmen Sanchidrián Blanco, delves into the origin of these institutions in the Spain of the Franco dictatorship. However, labor universities were not a Spanish invention. Actually, the model was imported directly from Belgium. This article not only talks about international connections during the first years of the dictatorship with different educational sectors. It also represents an advance from a methodological point of view since it tries to deepen the transnational process through an audiovisual analysis. For this, one of the most important propaganda news of the Franco regime, the NO-DO, is used.

Finally, this special issue closes its pages with another great contribution about the influence and processes of educational transfer that produced the public diplomacy agreements and the context of the Cold War. This last article, written by professors Ariclê Vechia and António Gomes Ferreira, focuses on analyzing the impact that the signing of agreements between Brazilian educational institutions and the US USAID had on the higher education reform process in the South American country. This case study represents another of the interesting examples to understand the wide network of new actors that originated after World War II and that functioned as mediators in the process of transformation of educational policy in different countries.

We hope that this special issue will be of interest to the reader. All the papers presented intend to continue with the advance of the transnational turn in the history of education. An analytical perspective that allows us to better understand how diplomatic connections between countries, the construction of educational networks, personal and institutional connections or the context of the Cold War, have configured a modern educational conception that goes far beyond national limits. 


\section{Note}

1. This research has been carried out under the framework of the research project: "Modernization, Development and Democratization. The Role of Western European Powers and International Organizations in Political and Social Change in Spain". This project is funded by the Ministry of Science, Innovation and Universities, Spain. Reference: PGC2018-097159-B-I00.

\section{References}

Adas, M. (2009). Dominance by Design: Technological Imperatives and America's Civilizing Mission. Cambridge: Belknap Press of Harvard University Press.

Åkerlund, A. (2014). The Impact of Foreign Policy on Educational Exchange: The Swedish State Scholarship Programme, 1938-1990. Paedagogica Historica, 50(3), 390-409.

Åkerlund, A. (2015). For Goodwill, Aid and Economic Growth: The Funding of Academic Exchange Through the Swedish Institute, 1945-2010. Nordic Journal of Educational History, 2(1), 119-140.

Allender, T. (2016). Learning Femininity in Colonial India, 1820-1932. Manchester: Manchester University Press.

Alves, L. A. \& Guimarães Lima, R. (2018). A Telescola ... é uma imensa sala de aula, do tamanho da lusitana faixa atlântica! Cadernos de História da Educação, 17(2), 491514.

Arnove, R., (ed.) (1980). Philanthropy and Cultural Imperialism: The Foundations at Home and Abroad. Boston: G.K. Hall\& Co.

Bagchi, B., Fuchs, E. \& Rousmaniere, K. (eds.) (2014). Connecting Histories of Education: Transnational and Cross-Cultural Exchanges in (Post)Colonial Education. New York: Berghahn.

Bruno-Jofré, R. \& Schriewer, J. (2012). The Global Reception of John Dewey's Thought: Multiple Refractions Through Time and Space. New York: Routledge.

Burke, C. Cunningham, P. \& Grosvenor, I. (2010). 'Putting Education in Its Place': Space, Place and Materialities in the History of Education. History of Education 39(6), 677-680.

Canales, A. F. (2019). From soul to matter: the new Spanish Francoist pedagogy's plunge into experimental pedagogy and the influence of Raymond Buyse. Paedagogica Historica, 55(3), 451-469.

Caruso, M. \& Roldán Vera, E. (2005). Pluralizing Meanings: The Monitorial System of Education in Latin America in the Early Nineteenth Century. Paedagogica Historica, 41(6), 645-654. 
Caute, D. (2005). The Dancer Defects: The Struggle for Cultural Supremacy during the Cold War. Oxford: Oxford University Press.

Charle, C., Schriewer, J. \& Wagner, P. (eds) (2004). Transnational Intellectual Networks: Forms of Academic Knowledge and the Search for Cultural Identities. Frankfurt am Main: Campus Verlag.

Chisholm, L. (2020). Transnational colonial entanglements: South African teacher education college curricula. In McCulloch, G., Goodson, I. \& González-Delgado, M. (eds.). Transnational Perspectives on Curriculum History (pp. 163-181). London: Routledge.

Christensen, I. L. \& Ydesen, C. (2015). Routes of Knowledge: Toward a Methodological Framework for Tracing the Historical Impact of International Organizations. European Education, 47(3), pp. 274-288.

Christophe, B., Gautschi, P. \& Thorp, R. (eds.) (2019). The Cold War in the Classroom: International Perspectives on Textbooks and Memory Practices, Cham: Palgrave Macmillan.

Christiansen, S. \& Zachary, S. A. (eds.) (2013). The Third World in the Global 1960s. New York: Berghahn Books, New York.

Clavin, P. (2005). Defining Transnationalism. Contemporary European History, 14, 421439.

Coombs, P. H. (1968). The World Educational Crisis: A Systems Analysis. New York: Oxford University Press.

Corrales Morales, D. (2020). Much Ado about Nothing? Lights and Shadows of the World Bank's Support of Spanish Aspirations to Educational Modernization (19681972). In Martín García, O. \& Delgado Gómez-Escalonilla, L. (eds.). Teaching Modernization Spanish and Latin American Educational Reform in the Cold War (pp. 127-149). New York: Berghahn Books.

Del Pozo Andrés, M. M. \& Braster, J. F. A. (2006). The Reinvention of the New Education Movement in the Franco Dictatorship (Spain, 1936-1976). Paedagogica Historica, 42(1-2), 109-126.

Del Pozo Andrés, M. M. \& Braster, S. (2017). El Plan Dalton en España recepción y apropiación (1920-1939). Revista de Educación, 377, 113-135.

Delgado Gómez-Escalonilla, L. (2009). Westerly Wind. The Fulbright Program in Spain. Madrid: Comisión Fulbright España-LID Editorial Empresarial-AECID.

Delgado Gómez-Escalonilla, L. (2015). Modernizadores y tecnócratas. Estados Unidos ante la política educativa y científica de la España del Desarrollo. Historia y Política, 34, 113-146.

Dorn, C. (2020). "A New Global Ethic": A History of the United Nations International Environmental Education Program, 1975-1995, Foro de Educación, 18(2), 83-108.

Dorn, C. \& Ghodsee, K. (2012). The Cold War Politicization of Literacy: Communism, UNESCO, and the World Bank. Diplomatic History, 36(2), 373-398. 
Droux, J. \& Hofstetter, R. (2014). Internationalisation in Education: Issues, Challenges, Outcomes. Paedagogica Historica, 50(1-2), 1-9.

Druick, Z. (2006). International cultural relations as a factor in postwar Canadian cultural policy: the relevance of UNESCO for the Massey Commission. Canadian Journal of Communication, 31(1), 177-195.

Duedahl, P. (2016). Out of the House: On the Global History of UNESCO, 1945-2015. In Poul Duedahl (ed.). A History of UNESCO: Global Actions and Impacts (pp. 3-25). London: Palgrave Macmillan.

Duedahl, P. (ed.) (2016). A History of UNESCO: Global Actions and Impacts. London: Palgrave Macmillan.

Evans, R. W. (2011). The Hope for American School Reform. The Cold War Pursuit of Inquiry Learning in Social Studies. New York: Palgrave Macmillan.

Ferraz Lorenzo, M. (2016). Un ejemplo de renovación pedagógica en Canarias durante los años 30: Tras el rastro y los retos de las técnicas Freinet. História da Educação, 20(50), 157-175.

Ferraz Lorenzo, M. (2020). Educación ambiental: Historia de un Nuevo contenido curricular surgido durante la transición democrática. In Ferraz Lorenzo, M. (ed.). Modernización educativa y socialización política Contenidos curriculares y manuales escolares en España durante el tardofranquismo y la transición democrática (pp. 307-330). Madrid: Morata.

Fuchs, E. \& Roldán Vera, E. (eds.) (2019). The Transnational in the History of Education: Concepts and Perspectives. Cham: Palgrave Macmillan.

Fuchs, E. (2007). Children's Rights and Global Civil Society. Comparative Education, 43(3), 393-412.

Fuchs, E. (2009). All the World into the School: World's Fairs and the Emergence of the School Museum in the Nineteenth Century." In Lawn, M. (ed). Modelling the Future: Exhibitions and the Materiality of Education (pp. 51-72). Oxford: Symposium Books.

Fuchs, E. (2014). History of Education beyond the Nation? Trends in Historical and Educational Scholarship. In Bagchi, B. Fuchs, E. \& Rousmaniere, K. (eds.). Connecting Histories of Education: Transnational and Cross-Cultural Exchanges on (Post-) Colonial Education (pp. 11-26). New York: Berghahn Books.

Gienow-Hecht, J. \& Donfried, M. (2010). The Model of Cultural Diplomacy: Power, Distance, and the Promise of Civil Society. In Gienow-Hecht, Jessica \& Donfried, Mark (eds.), Searching for a Cultural Diplomacy (pp. 13-32). New York: Berghahn Books.

Gienow-Hecht, J. (2010). Culture in the Cold War. In Leffler, M. \& Westad, O. A. (eds.). The Cambridge History of the Cold War (pp. 398-419). Cambridge: Cambridge University Press.

Gilboa, E. (2008). Searching for a Theory of Public Diplomacy. The Annals of the American Academy of Political and Social Sciences, 616, 55-77. 
Gilman, N. (2003). Mandarins of the Future: Modernization Theory in Cold War America. Baltimore: The Johns Hopkins University Press.

Goedde, P. (2017). ¿Power, Culture, and the Rise of Transnational History in the United States'. The International History Review, 40(3), 592-608.

González-Delgado, M. \& Groves, T. (2016). Influencias extranjeras en la formación continua del profesorado en el segundo franquismo. En Martín-Sánchez, M., \& Groves, T. (Eds.), La formación del profesorado. Nuevos enfoques desde la teoría y la historia de la educación (pp. 51-64). Salamanca: FarenHouse.

González-Delgado, M. \& Groves, T. (2017). La enseñanza programada, la UNESCO y los intentos por modificar el curriculum en la España desarrollista (1962-1974). Espacio, Tiempo y Educación, 4(2), 73-100.

González-Delgado, M. \& Groves, T. (2020). Educational Transfer and Local Actors: International Intervention in Spain during the Late Franco Period. In Martín García, O. \& Delgado Gómez-Escalonilla, L. (eds.). Teaching Modernization Spanish and Latin American Educational Reform in the Cold War (pp. 101-127). New York: Berghahn Books.

González-Delgado, M. (2018). The modernization of curriculum policy in Late Francoism: The UNESCO and the International Understanding Programme in Spain. BERA Conference, Newcastle, 11th-13th September 2018, Northumbria University.

González-Delgado, M. (2020). «Estar a la altura de nuestro tiempo»: la televisión educativa, la UNESCO y la modernización de la enseñanza en el franquismo, Hispania, 80(265), pp. 597-627.

González-Delgado, M. Ferraz Lorenzo, M. \& Machado-Trujillo, C. (2019). The concept of the State in textbooks: Analysis and reinterpretation during the Spanish Transition to Democracy (1976-1986), British Journal of Educational Studies, doi: https://doi.org/10.1080/00071005.2019.1645810

Goodman, J., McCulloch, G. \& Richadson, W. (2009). "Empires overseas" and "empires at home": postcolonial and transnational perspectives on social change in the history of education. Paedagogica Historica, 45(6), 695-706.

Goodson, I. \& Mikser, R. (2020). Patrones de diferenciación en las reformas neoliberales de la educación: La transición educativa en los antiguos países socialistas europeos y el concepto de refracción. In Ferraz Lorenzo, M. (ed.). Modernización educativa y socialización política Contenidos curriculares y manuales escolares en España durante el tardofranquismo y la transición democrática (pp. 97122). Madrid: Morata.

Graham, S. E. (2006). The (Real) politics of Culture: U.S. Cultural Diplomacy in UNESCO, 1946-1954. Diplomatic History, 30(2), 231-251.

Groves, T. (2015). A foering model of teacher education and its local appropriation: the English teachers' centres in Spain. History of Education, 44(3), 355-370.

Hallström, J. Hultén, M. \& Lövheim, D. (2014). The study of technology as a field of knowledge in general education: historical insights and methodological 
considerations from a Swedish case study, 1842-2010. International Journal of Technology and Design Education, 24, 121-139.

Hiraoka, M. (2020). Transnational information flow and domestic concerns: Japanese educational exhibits in the late nineteenth and early twentieth centuries in Britain. In McCulloch, G., Goodson, I. \& González-Delgado, M. (eds.). Transnational Perspectives on Curriculum History (pp. 108-131). London: Routledge. Igelmo-Zaldívar, J. \& Jover Olmeda, G. (2019). Cuestionando la narrativa del aprendizaje servicio a partir de dos iniciativas de extensión social universitaria de orientación católica en la década de 1950 en España. Utopía y praxis latinoamericana: revista internacional de filosofía iberoamericana y teoría social, 87, 151-162.

Igelmo-Zaldívar, J., Jover Olmeda, G. \& Quiroga-Uceda, P. (2020). «HABLAR POCO Y HACER MUCHO»: Las campañas de educación popular - una iniciativa del servicio universitario del trabajo para las universidades españolas (1962-1968), Revista História da Educação, 24, 1-29.

Igelmo-Zaldívar, J. (2012). Las teorías de la desescolarización: Cuarenta años de perspectiva histórica. Social and Education History, 1(1), 28-57.

Isozaki, T. (2016). Historical insights into British, Japanese and US general science from the first half of the twentieth century. Asia-Pacific Science Education, 2(1), 116.

Jones, P. W. (1999). Globalisation and the UNESCO mandate: multilateral prospects for educational development. International Journal of Educational Development, 19, 17-25.

Jones, P. W. 2006. Education, Poverty and the World Bank. New York: Sense Publishers.

Jover Olmeda, G. \& Thoilliez Ruano, B. (2011). La pedagogía «au pluriel» y su incidencia en la reformulación del conocimiento teórico de la educación en España. In Hernández Díaz, J. M. (ed.). Francia en la educación de la España contemporánea (1808-2008) (pp. 2019-247). Salamanca: Prensas Universitarias de la Universidad de Salamanca.

Latham, M. (2010). The Cold War in the Third World, 1963-1975. In Westad, O. A. \& Leffler (eds.). The Cambridge History of the Cold War, (pp. 258-280). Cambridge: Cambridge University Press.

Laville, H. \& Wilford, H. (2006). The US Government, Citizen Groups and the Cold War: The State-Private Network. London: Routledge.

Lindo-Fuentes, H. (2009). Educational Television in El Salvador and Modernisation Theory. Journal of Latin American Studies, 41, 757-792.

Lindo-Fuentes, H., \& Ching, E. (2012). Modernizing Minds in El Salvador: Education Reform and the Cold War, 1960-1980. Albuquerque: University of New Mexico Press. 
Mahamud Angulo, K. \& Milito Barone, C. (2020). Estancias y consultores para la formación del profesorado. Un pilar estratégico del intercambio cultural ente España y Estados Unidos (1960-1976). In Ferraz Lorenzo, M. (ed.). Modernización educativa y socialización política Contenidos curriculares y manuales escolares en España durante el tardofranquismo y la transición democrática (pp. 151-190). Madrid: Morata.

Mangan, J. A. (ed.) (1993). The Imperial Curriculum: Racial Images and Education in the British Colinial Experience. London: Routledge.

Mariuzzo, A. (2016). American cultural diplomacy and post-war educational reform: James Brynt Conant's misión to Italy in 1960. History of Education, 45(3), 352-371. Martín García, Ó. (2019). 'The Most Developed of the Underdeveloped Nations'. US Foreign Policy and Student Unrest in 1960s Spain. The International History Review, 41(3), 539-558.

Martín García, Ó. \& Delgado Gómez-Escalonilla, L. (eds.) (2020). Teaching Modernization Spanish and Latin American Educational Reform in the Cold War. New York: Berghahn Books.

Martín García, Ó. \& Mgnúsdottir, R. (eds.) (2019). Machineries of Persuasion: European Soft Power and Public Diplomacy during the Cold War. Berlin: De Gruyter Oldenbourg.

Martín-García, Ó. (2013). A complicated mission: The United States and Spanish students during the Johnson administration. Cold War History, 13(3), 311-329.

Martín-García, Ó. (2015). Una utopía secular. La teoría de la modernización y la política exterior estadounidense en la Guerra Fría. Historia y Política, 34, 27-52.

McCulloch, G. \& Cowan, S. (2018). A Social History of Educational Studies and Research. London: Routledge.

McCulloch, G. (2009). Empires and Education: The Bristish Empire. In Cowen, R. \& Kazamias, A. (eds.). Handbook of Comparative Education (pp. 169-179). Dordrecht: Springer.

McCulloch, G., \& Lowe, R. (2003). Introduction: Centre and periphery: networks, space and geography in the history of education. History of Education, 32(5), 457-459.

McCulloch, G., Goodson, I. \& González-Delgado, M. (eds.) (2019). Transnational Perspectives on Curriculum History. London: Routledge.

McMahon, Robert (ed.) (2013). The Cold War in the Third World. Oxford: Oxford University Press.

Meyer, J. W., Ramirez, F. O., Rubinson, R., \& Boli, J. (1977). The World Educational Revolution, 1950-1970. Sociology of Education, 50(4), 242-258.

Mikobi Dikay, J. (2016). Education for Independence: UNESCO in the Post-colonial Democratic Republic of Congo. In Poul Duedahl (ed.). A History of UNESCO: Global Actions and Impacts (pp. 168-180). London: Palgrave Macmillan. 
Mundy, K. (2006). The Evolution of Educational Multilateralism from 1945 to 2005. In Fuchs, E. (ed.). Bildung International: Historische Perspektiven und aktuelle Entwicklungen (pp. 181-199). Würzburg: Ergon-Verl.

Negrín Fajardo, O. (2013). España en África Subsahariana. Legislación educativa y aculturación coloniales en la Guinea Española (1857-1959). Madrid: Dykinson.

Nye, J. (1990). Bound to lead: The Changing Nature of American Power. New York: Basic Books.

Nye, J. (2004). Soft Power: The Means to Success in World Politics. New York: Public Affairs.

Nye, J. (2008). The Powers to Lead. Oxford: Oxford University Press.

Nygren, T. (2011) International reformation of Swedish history education 1927-1961: The complexity of implementing international understanding. Journal of World History, 22(2), 329-354.

Ochs, K. \& Phillips, D. (eds) (2004). Educational Policy Borrowing: Historical Perspectives. Oxford: Symposium Books.

Osgood, K. \& Etheridge, B. (2010). Introduction. The New International History Meets the New Cultural History: Public Diplomacy and U.S. Foreign Relations. In Osgood, K. \& Etheridge, B. (eds). The United States and Public Diplomacy: New Directions in Cultural and International History (pp. 1-25) Boston: Martinus Nijhoff.

Ossenbach, G. \& Del Pozo Andrés, M. M. (2011). Postcolonial Models, Cultural Transfer and Transnational Perspectives in Latin America: A Research Agenda. Paedagogica Historica 47(5), 579-600.

Ossenbach, G. \& Groves, T. (2013). Entre la mitificación y la crítica: el cine y los medios audiovisuales en la escuela primaria en España en el tardofranquismo y la transición, 1958-1982. Cahiers de civilisation espagnole con contemporaine, 11, 217.

Ossenbach, G., \& Martínez Boom, I. (2011). Itineraries of the discourses on development and education in Spain and Latin America (circa 1950-1970). Paedagogica Historica, 47(5), 679-700.

Otero-Urtaza, E. (2013). The educational Missions under the Second Republic in Spain (1931-1936): a framework for popular education. In Braster, S., Simon, F., \& Grosvenor, I. (eds.), A History of Popular Education. Educating the People of the World (pp. 207-220). London: Routledge.

Phillip W. J. \& Coleman, D. (2005). The United Nations and Education: Multilateralism, Development and Globalisation. London: Routledge.

Phillips, D. \& Ochs, K. (2004). Researching policy borrowing: some methodological challenges in comparative education. British Educational Research Journal, 30(6), 773-784.

Popkewitz, T. S. \& Rizvi, F. (eds.) (2009). Globalization and the Study of Education. Malden: Wiley-Blackwell. 
Popkewitz, T. S. (2009) Globalizing Globalization: The Neo-institutional Concept of a World Culture. National Society for the Study of Education, 108(2), 29-49.

Prytz, J. \& Ringarp, J. (2020). Local versus national history of education: The case of Swedish school governance, 1950-1990. In McCulloch, G., Goodson, I. \& González-Delgado, M. (eds.). Transnational Perspectives on Curriculum History (pp. 131-149). London: Routledge.

Raftery, D. (2015). Teaching Sisters and Transnational Networks: Recruitment and Education Expansion in the Long Nineteenth Century. History of Education, 44(6), 717-728.

Ramirez, F. \& Boli, J. (1987). The Political Construction of Mass Schooling: European Origin and Worldwide Institutionalization. Sociology of Education, 60(1), 2-17. Rogers, R. (2013). A Frenchwoman's Imperial Story: Madame Luce in NineteenthCentury Algeria. Stanford: Stanford University Press.

Roldán Vera, E. (2013). Para desnacionalizar la historia de la educación: Reflexiones en torno a la difusión mundial de la escuela lancasteriana en el primer tercio del siglo XIX. Revista Mexicana de Historia de la Educación 1(2), 171-198.

Rudolph, J. L. (2002) Scientist in the Classroom. The Cold War Reconstruction of American Science Education. New York: Palgrave.

Schultz, T. (1968). Valor económico de la educación. México: UTEHA.

Scott-Smith, G. (2014). Private Diplomacy: Making the Citizen Visible. New Global Studies, 8(1), 1-7.

Sivesind, K., \& Wahlström, N. (2016). Curriculum on the European policy agenda: Global transitions and learning outcomes from transnational and national points of view. European Educational Reseach Journal, 15(3), 271-278.

Snider, C. (2013). A More Systemic Fight for Reform: University Reform, Student Movements, Society, and the State in Brazil, 1957-1968. In Christiansen, S. \& Scarlett, Z. (eds.). The Third World in the Global 1960s1(pp. 101-115). New York: Berghahn Books.

Snider, C. (2020). Passing through a Critical Moment" The United States and Brazilian University Reform in the 1960s. In Martín García, O. \& Deñlgado Gómez- Escalnilla, L. (eds). Teaching Modernization: Spanish and Latin American Educational Reform in the Cold War (pp. 195-220). New York, Berghahn Books.

Snow, N. (2009). Rethinking Public Diplomacy. In Snow, N. \& Taylor, P. (eds.). Routledge Handbook of Public Diplomacy (pp. 3-12). London: Routledge. Snyder, S. (2013). Bringing the Trasnational In: Writing Human Rights into the International History of the Cold War. Diplomacy and Statecraft, 23, 100-116.

Sobe, N. W. (2013). Entanglement and Transnationalism in the History of American Education. In Popkewitz, T. S. (ed.). Rethinking the History of Education: Transnational Perspectives on Its Questions, Methods, and Knowledge (pp. 93107). Basingstoke: Palgrave Macmillan. 
Struck, B., Ferris, K. \& Revel, J. (2011). Introduction: Space and Scale in Transnational History. The International History Review, 33(4), 573-584.

Terrón, A. Comelles, J. \& Perdiguero-Gil, E. (2017). Schools and health education in Spain during the dictatorship of General Franco (1939-1975). History of Education Review, 46(2), pp. 208-223.

Tournès, L. \& Scott-Smith, G. (2017). A World of Exchanges. Conceptualizing the History of International Scholarship Programs (Nineteenth to Twenty-First Centuries). In Tournès, L. \& Scott-Smith, G. (eds.). Global Exchanges. Scholarships and Transnational Circulations in the Modern World (pp. 1-19). New York: Berghahn Books.

Tröhler, D. Popkewitz, T. S. \& Labaree, D. F. (eds.) (2011). Schooling and the Making of Citizens in the Long Nineteenth Century: Comparative Visions. New York: Routledge.

Trölher, D. (2013). The technocratic Momentum after 1945, the Development of Teaching Machines, and Sobering Results. Journal of Educational, Media, Memory, and Society, 5(2), pp. 1-19.

Tyrrell, I. (2007) Transnational Nation. United States History in Global Perspective since 1789. Basingstoke: Palgrave Macmillan.

Viñao, A. (1990). Innovación pedagógica y racionalidad científica: La escuela graduada pública en España (1898-1936). Madrid: Akal.

Wallerstein, I. M. (1974). Capitalist Agriculture and the Origins of the European WorldEconomy in the Sixteenth Century. New York: Academic Press.

Weisbrode, K. (2013). Old Diplomacy Revisited. Basingstoke: Palgrave Macmillan. Westad O. A. (2000). The New International History of the Cold War: Three (Possible) Paradigms. Diplomatic History, 24, 551-565.

Westad, O. A. (2003). The Global Cold War. Third World Interventions and the Making of Our Times. Cambridge: Cambridge University Press.

Westberg, J. (2019). How did teachers make a living?: The teacher occupation, livelihood diversification and the rise of mass schooling in nineteenth-century Sweden. History of Education, 48(1), 19-40.

Westberg, J. (2020). Combining Global and Local Narratives: A New Social History of the Expansion of Mass Education?, European Education, doi: 10.1080/10564934.20 20.1727750

Westberg, J., Boser, L. \& Brühwiler, I. (eds.) (2019). School Acts and the Rise of Mass Schooling Education Policy in the Long Nineteenth Century. Cham: Palgrave Macmillan.

Ydesen, Ch. (ed.) (2019). The OECD's Historical Rise in Education: The Formation of a Global Governing Complex. Cham: Palgrave Macmillan. 